\title{
Financial literacy of young people with different self-fulfillment strategies
}

\author{
Elena Scherbina*,Olesya Shestopalova, Daria Demicheva and Sergey Akhtyrsky \\ Southern Federal University, 344006, Rostov-on-Don, Russia
}

\begin{abstract}
The article presents the results of an empirical study of the money orientation of young people with different self- fulfillment strategies. Self- fulfillment is viewed as a complex psychological phenomenon that includes needs, motives in achieving vital goals associated with the implementation of the self-concept and manifested in the desire for recognition, self-realization, achievement of role-based personal certainty and maintaining a certain social status. Our approach to the research topic was based on the position that self- fulfillment and the need for financial independence are becoming relevant for young people.Self- fulfillment can be achieved in different ways. One of these means can be considered money as a motive for human behavior. In our study, we proceeded from the assumption that there will be differences in the orientation towards money among young people with different strategies of self-affirmation. The study involved 94 young people aged $18-22$.
\end{abstract}

\section{Introduction}

The changes taking place in modern society, associated with digitalization, the introduction of new forms of representation of everyday experience, have led to the transformation of personal behavior strategies, including monetary behavior.

Our approach to this research topic is based on the position that self- fulfillment and the need for financial independence become relevant for young people.

Self- fulfillment is a complex psychological phenomenon in which the following components can be distinguished:

- this is the process of active interaction of a person with his environment, during which his self-realization occurs, affecting the interests, emotions, views, values of partners;

- self- fulfillment includes the needs and motives for achieving vital goals (recognition, power, self-fulfillment, success);

- self- fulfillmentis implemented in various strategies;

- self- fulfillmentis related to the self-concept of a person;

- the function of self-affirmation consists in a person's desire for recognition, selfactualization, achievement of role and personal certainty, liberation from dependence.

A number of modern studies are devoted to the study of self- fulfillment, its various aspects, including as a form of social activity.

*Corresponding author: sherbina_e@mail.ru 
.These are works aimed at identifying the effect of self- fulfillment on the reduction of social anxiety (Lakuta,) [1] stressful situations (Creswell, JD, Dutcher, JM , Klein, WMP , Harris, PR , Levine, JM) [2], on the academic achievements of students belonging to different ethnic groups (GD. Borman, Grigg, J. Rozek, CS. Hanselman, P. Dewey, NA) [3], on the study of individual differences in self-affirmation (Harris, PR, Griffin, DW. and others) [4].

Self- fulfillment can be achieved using different methods and means.

One of these means can be considered money as a motive for human behavior. Orientation towards money is the desire to increase one's wellbeing, which manifests itself in the monetary behavior of a person and demonstrates a different attitude towards money.

There are several leading models of monetary behavior based on the rules of relations with money: rational, traditional, altruistic, irrational. A rational model of behavior is characterized by tight control of the balance of savings and spending, money is seen as a means to achieve various life goals: ensuring optimal consumption in accoring with the level of income and living standards, accumulating them to meet social needs and needs in the future, and reservation in accordance with intentions, capitalize the free part of the income.

The altruistic model is characterized by a gratuitous spending of money based on empathic motives, feelings, as well as on religious attitudes and prescriptions that limits the selfish motives of monetary behavior.

An irrational model is a consequence of insufficient competence in dealing with money or a distortion of the objective functions of money.

The study of the motivation of monetary behavior and attitudes towards money is relevant for modern research.

Money is studied as a motive of human behavior, the relationship between attitudes towards money and other personal and behavioral characteristics of a person.

For example, it was revealed that financial independence is an attribute of personal independence as a key characteristic of adulthood (Butterbaugh, SM, Ross, DB, Campbell, A.) [5], that a low orientation towards money is dominated among ambitious young people (Barsukova, Oksana V., Barsukova Arina V.) [6], and people with a low level of orientation towards money are more satisfied with their income regardless of how much they earn (Chitchai N., Senasu K., Sakworawich A.)[7], that individuals with an orientation "to be" rather than "to have" have greater life satisfaction (Kruczek, A., Janicka, M.) [8], that an important factor in the monetary behavior of an individual the formation of attitudes and behavior is not only education in the field of personal finance, but also financial education in a modern family (Gudmunson, CG, Danes, SM)[9], that the peculiarities of parent-child relations have an impact on the nature of financial activity and independence of young people (Zhdanova, N.E and jthers) [10], that basing self-worth on financial success is associated with a greater sense of loneliness and social disconnection, (Ward, DE, Park, LE, Naragon-Gainey, K., Whillans, AV, Jung, HY) [11]

The studies that consider the view of the nature of money as a system of meanings and signs(Pashkov, S.)[12], the influence of culture and economy on the formation of monetary values (Ilgaroğlu, MC)[13], motives for making money and life satisfaction (Zhao, N., Lai, H.,Zhao, R.) [14], the relationship between difficulties in meeting basic needs, including financial ones, and the influence of students on their ability to learn (Kumsa, M.J., Lemu, B.N. and others)[15] have particular interest.

\section{Materials and methods}

In our study, we assumed that there would be differences in the money orientation of young people with different self- fulfillment strategies. The empirical study was conducted using 
two methods: "Diagnostics of strategies of self- fulfillment of the individual" (N. E. Kharlamenkova, E. P. Nikitin). Test for the diagnosis of socio-psychological personality attitudes in the motivational-need sphere (O. Potemkina). For the mathematical and statistical processing of the obtained data, the Fisher $\varphi$-criterion was used. The study involved 94 people aged 18-22 years.

\section{Results}

The study of self- fulfillment strategies allowed us to obtain the following results (Table 1): The strategy of "constructive self- fulfillment" was revealed in slightly more than half of young people-55.32\%. Constructive self-expression manifests itself in establishing positive relationships with other people, in mutual assistance, in productive activities and creativitythis allows a person to feel their self-worth. The strategy of "aggressive self- fulfillment" was revealed in the minimum number of young people- $4.26 \%$. This strategy manifests itself in the suppression of other people, there is aggression in the behavior-it is this behavior that causes a sense of satisfaction in a person with this strategy. The strategy of "rejection of self- fulfillment" was revealed in $40.43 \%$ of young people. This strategy manifests itself in avoiding situations where it is necessary to take the initiative, in the tendency to hide one's own opinion and adequate emotional reactions, in the preference for vague and lowexpressive forms of speech communication.

Table 1. Strategies for self-affirmation

\begin{tabular}{|c|c|c|}
\hline $\begin{array}{c}\text { Constructive of self- } \\
\text { fulfillment }\end{array}$ & $\begin{array}{c}\text { Rejection of } \\
\text { self- fulfillment }\end{array}$ & $\begin{array}{c}\text { Aggressive of } \\
\text { self- fulfillment }\end{array}$ \\
\hline $55.32 \%$ & $40.43 \%$ & $4.26 \%$ \\
\hline
\end{tabular}

Next, we conducted a study of the orientation of young people with different strategies of self- fulfillment.

The study of money orientation in young people with strategies of "constructive selffulfillment" showed that the average score is 2.61 points (range of low values), the range of points is from 1 to 8 , while:

- low orientation to money was revealed in $84.61 \%$ of young people;

- the average orientation to money was revealed in $7.69 \%$ of young people;

- high orientation to money in these young people is not revealed.

The study of money orientation in young people with strategies of " self- fulfillment rejection" showed that the average score is 2.53 points (low range), the range of points is from 1 to 5, while:

- low orientation to money was revealed in $94.74 \%$ of young people;

- average money orientation was found in $5.26 \%$ of young people;

- high orientation to money in these young people is not revealed.

A study of money orientation in young people with strategies of "aggressive selffulfillment" revealed that all of them have only a low orientation on money, the average score is- 1.00 points (the range of low values).

A comparative analysis of the money orientation of young people with different selffulfillment strategies did not reveal significant differences (Table 2). Young people with the "aggressive self- fulfillment" strategy did not participate in the further study due to the small number of the sample. So:

-Low money orientation prevails among young people with the strategy of " selffulfillment rejection" (94.74\%) compared to young people with the strategy of "constructive self- fulfillment" $(84.61 \%)$. But these differences are not significant $(\varphi=1.133, \mathrm{p}=0.05)$. 
-The average orientation to money prevails in young people with the strategy of "constructive self- fulfillment" $(7.96 \%)$ compared to young people with the strategy of "rejection of self- fulfillment" (5.26\%). But these differences are not significant $(\varphi=1.133$, $\mathrm{p}=0.05$ ).

- A high orientation to money was not revealed in young people with different selffulfillment strategies

Table 2. Focus on the money of young people with different strategies of selfaffirmation.

\begin{tabular}{|c|c|c|c|}
\hline & $\begin{array}{c}\text { Constructive of self- } \\
\text { fulfillment }\end{array}$ & $\begin{array}{c}\text { Rejection of self- } \\
\text { fulfillment }\end{array}$ & $\begin{array}{c}\text { Significance of } \\
\text { differences }\end{array}$ \\
\hline $\begin{array}{c}\text { Low focus on } \\
\text { money }\end{array}$ & $84.61 \%$ & $94.74 \%$ & $\varphi=1.133, \mathrm{p}=0.05$ \\
\hline $\begin{array}{c}\text { Average money } \\
\text { orientation }\end{array}$ & $7.69 \%$ & $5.26 \%$ & $\varphi=1.133, \mathrm{p}=0.05$ \\
\hline
\end{tabular}

\section{Discussion}

The results obtained did not confirm the proposed assumption that there will be differences in the orientation towards money among young people with different strategies of selffulfillment. Young people with different strategies of self- fulfillment are dominated by a low orientation towards money. And, if a low orientation towards money among young people with a strategy of "refusal of self- fulfillment" can be accepted, then the prevalence of a low orientation towards money among young people seeking to assert themselves in one way or another needs further reflection. It can be assumed that a high orientation towards money among young people with a strategy of "constructive self- fulfillment" is not a status one, since disinterested behavior, a high level of competence, and commitment to a group are viewed by them as the shortest path to recognition, a high reputation among members group. This seemingly selfless behavior leads to the fact that they are perceived as more generous, which leads to a higher status and allows them to take a higher social level. The low orientation towards money among young people with the strategy of "aggressive self-assertion" may be caused by the fact that money is not considered by them as a powergenerating resource. We can assume that for this category of young people, status is prestige, a leading position, the ability to control information, influence the behavior of another person, etc. There may also be individual characteristics in the propensity to carry out actions of self-determination. The results obtained make us think and reconsider the role of money in the lives of modern young people. It can be assumed that money is not the main value and the leading motive for self- fulfillment of young people. Probably, they associate their self- fulfillment with other goals, they are guided by other motives that are to be revealed in further research.

\section{Conclusions}

An empirical study revealed that young people have two strategies of self- fulfillment"constructive self- fulfillment" and "rejection of self- fulfillment". 
A minimum number of young people have a strategy of "aggressive self- fulfillment". The results of the comparative study did not confirm our assumption about the differences in the money orientation of young people with different self- fulfillment strategies.

Young people with the strategy of "constructive self- fulfillment" and with the strategy of "rejection of self- fulfillment" have a low orientation to money, the minimum number of them is represented by an average orientation to money, a high orientation to money is not revealed.

Our research will continue, in particular, we plan to increase the sample of the study, to study the orientation to money in a larger number of young people with the strategy of "aggressive self- fulfillment". We also plan to study other motivations that are more pronounced in young people.

\section{References}

1. P. Łakuta, Anxiety, Stress and Coping 33(4), 370-386 (2020). doi. org. $10.1080 / 10615806.2020 .1746283$

2. J.D. Creswell, J.M. Dutcher, W.M.P. Klein, P.R. Harris, J.M. Levine, PLoS ONE 8 (5), (2013). doi. org. 10.1371/journal.pone.0062593

3. G.D. Borman, J. Grigg, C.S. Rozek, P. Hanselman, N.A. Dewey, Psychological Science 29(11), 1773-1784 (2018). doi.org. 10.1177/0956797618784016

4. P.R. Harris, D.W. Griffin, L.E. Napper, (...), C. Stride, I. Brearley, Self and Identity 18(6), 589-630 (2019). doi.org. 10.1080/15298868.2018.1504819

5. S.M. Butterbaugh, D.B. Ross, A. Campbell, Contemporary Family Therapy 42(1), 3345 (2020). doi.org. 10.1007/s10591-019-09515-8

6. O.V. Barsukova, A.V. Barsukova, Journal of Process Management - New Technologies, International 9(1), 20-22 (2021). doi.org.10.5937/jouproman9-29873

7. N. Chitchai, K. Senasu, A. Sakworawich, Kasetsart Journal of Social Sciences 41, 336-344 (2020). doi.org. 10.1016/j.kjss.2018.08.002

8. A. Kruczek, M. Janicka, Psychiatriai Psychologia Kliniczna 19(2), 158-164 (2019). doi.org 10.15557/PiPK.2019.0016

9. C.G. Gudmunson, S.M. Danes, Journal of Family and Economic Issues 32(4), 644-667 (2011). doi.org. 10.1007/s10834-011-9275-y

10. N.E. Zhdanova, I.V. Vorobeva, M.S. Krivoshchekova, S.I. Velkova, Obrazovanie i Nauka 22(7), 33-51 (2020). doi.org. 10.17853/1994-5639-2020-33-51

11. D.E. Ward, L.E. Park, K. Naragon-Gainey, A.V. Whillans, H.Y. Jung, Personality and Social Psychology Bulletin 46(12), 1665-1681 (2020). doi.org 10.1177/0146167220910872

12. S. Pashkov, Ekonomicheskaya Sotsiologiya 2020 21(5), 94-109 (2020). doi.org10.17323/1726-3247-2020-5-94-109.

13. M.C. Ilgaroğlu, Cumhuriyet Ilahiyat Dergisi 23(3), 1331-1347 (2019). doi.org 10.18505/cuid.615224

14. N. Zhao, H. Lai, R. Zhao, PsyCh Journal 10(1), 76-86 (2021). doi.org 10.1002/pchj. 381

15. M.J. Kumsa, B.N. Lemu, T.M. Nguse, PLoS ONE 15(12), (2020). doi.org: 10.1371/journal.pone.0243634 